\title{
A case report of seronegative cat scratch disease, emphasizing the histopathologic point of view
}

\author{
Ok Ran Shin ${ }^{1}$, Yang Ree Kim², Tae-hyun Ban², Taeseok Lim², Tae Hee Han, Su Yeon Kim and Kyung Jin Seo ${ }^{\text {* }}$
}

\begin{abstract}
Cat scratch disease, necrotizing granulomatous lymphadenitis caused by Bartonella henselae, usually benign and self-limited. However, various clinical manifestations and no pathognomonic histopathologic features can lead to misinterpretations and diagnostic disputes. We report a case of cat scratch disease in a 39-yr-old male patient with fever and left axillary lymphadenitis. He had a history of cat bite on the left hand dorsum. On excision, the lymph node showed follicular hyperplasia, stellate microabscesses with a rim of granulomatous inflammation. Warthin-Starry silver staining showed many clumps of silver-stained bacilli within the necrotic foci. Serological tests were negative. Diagnosis was established by PCR analysis.
\end{abstract}

Virtual slides: The virtual slides for this article can be found here: http://www.diagnosticpathology.diagnomx.eu/vs/ 1877499238123059

Keywords: Cat scratch disease, Bartonella, Warthin-Starry silver stain, PCR, Histological features, Differential diagnosis

\section{Letter to the editor}

Cat scratch disease (CSD) is caused by Bartonella henselae [1-3]. The pathogens are transmitted by bites or scratches from infected cats. Usually a unilateral lymphadenitis near the scratch, bite site develops 2-3 weeks after infection. CSD is a common cause of chronic lymph node swelling in children and adolescents [1-3]. Histopathologically, the affected lymph node shows granuloma with microabscess formation, which is not pathognomonic. We present a case of CSD, serologically negative but positive by Warthin-Starry (WS) stain and confirmed by PCR, discuss histopathologic features and review the literature, emphasizing histopathologic differential diagnosis.

A 39-year-old male patient was admitted with painful swelling in the left axilla and elbow and fever for 3 weeks. He had a history of cat bite on the left hand dorsum 3 weeks before admission. His temperature was $39.3^{\circ} \mathrm{C}$. A rash was noted on the left hand dorsum. Two tender palpable lymph nodes were present at the left axillary and epitrochlear regions. Laboratory results were unremarkable. Liver enzymes were normal. Blood cultures and viral serologic tests results were all negative.

\footnotetext{
* Correspondence: ywacko@catholic.ac.kr

'Department of Hospital Pathology, Uijeongbu St. Mary's Hospital College of Medicine, The Catholic University of Korea 271, Cheonbo-ro, Uijeongbu-si, Gyenggi-do 480-717, Republic of Korea

Full list of author information is available at the end of the article
}

An indirect fluorescence assay (IFA, commercial kit) against Bartonella (B.) quintana and B. henselae gave negative results (IgG $<1: 16$, IgM $<1: 16)$. Serologic tests for Tularemia and Toxoplasmosis were also negative. Although the fever subsided after 3 days of antibiotics, the axillary lymphadenopathy didn't resolve and an excisional biopsy of the affected lymph nodes was performed.

Pathologically, the lymph node demonstrated granulomatous inflammations with multiple stellate microabscesses with numerous neutrophils within the necrotic foci (Figure 1A \& B). Culture results were negative for any other microbes. The Brown-Brenn Gram stain was negative. A PAS and a methenamine silver stain showed no fungal species, but the WS stain showed some clumps of silver-stained bacilli in areas of the necrosis (Figure 1C). The final diagnosis was established by PCR using formalinfixed paraffin-embedded (FFPE) lymph node tissue. PCR was performed with the primer sets (PAPn1, PAPn2, and PAPns2) for the pap31 gene, according to the previous description by Zeaiter et al. (Figure 1D) [4].

Ever since the first description by Robert Debre in 1931, the terminology of Bartonella species have experienced some changes [3,5-7]. Briefly, in 1993, B. henselae is recognized as the causative agent of CSD [8-13]. Most patients with CSD have cat exposures, i.e. scratches or bites $[3,7,14]$. The most typical form of CSD manifests as tender, regional lymphadenopathy 2 weeks after an 


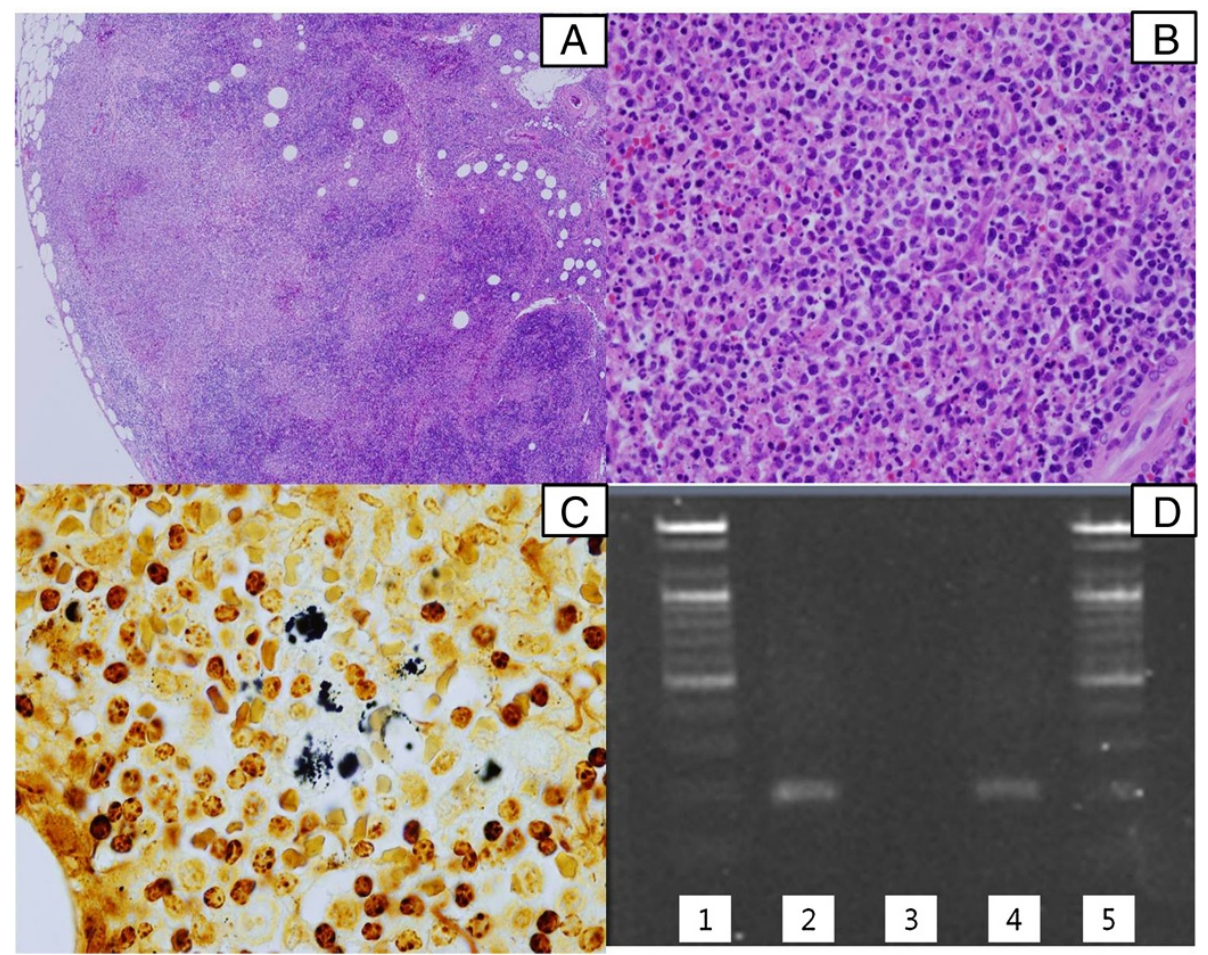

Figure 1 Histopathology, silver stain and PCR of Cat scratch disease. (A) The affected lymph node showed reactive follicular hyperplasia and multiple geographic microabscesses (H\&E stain $\times 40$ ). (B) Numerous neutrophils are seen in the necrotic foci of the lymph node (H\&E stain $\times 400)$. (C) Some clumps of bacteria were found in the lymph node (Warthin-Starry silver stain $\times 1,000$ ). (D) Results of semi-nested polymerase chain reaction (PCR) for the B. henselae pap 31 gene (211 bp). From the left column, Lanes 1-5: Lane 1 and 5, DNA ladder marker (Bioneer, Daejeon, Korea); lane 2, positive control (Houston-1, ATCC 49882); lane 3, negative control; lane 4, lymph node tissue from the patient.

inoculation. The results of routine lab studies are unremarkable $[3,15]$. Systemically, most patients might experience fever, generalized aches, malaise, anorexia, nausea, and abdominal pain [5,9].

As Florin et al. summarized, clinical manifestations of $B$. henselae are expanding, and the list includes typical CSD (fever and localized lymphadenopathy only), prolonged fever/fever of unknown origin and hepatosplenic disease, and less common various manifestations [9].

Culture is not reliable for the diagnosis of CSD, as the organism is slow-growing and difficult to culture $[3,16]$. More recently, Serology and PCR have been applied widely [9]. Despite high specificity (100\% in 1 study), PCR shows a low sensitivity, ranging from $43 \%$ to $76 \%$ $[9,17,18]$. A more practical means is a serology for $B$. henselae antibodies $[9,19]$. One of the serologic test is an indirect fluorescence assay (IFA) [9]. In our case, serologic test, i.e. IFA gave negative results $(\operatorname{IgG}<1: 16$, IgM $<1: 16)$. However, PCR assay of FFPE lymph node tissue was positive.

Tissue biopsy is one useful way to diagnose CSD and to exclude other etiologies, despite its invasive nature $[3,9]$. Silver impregnation stains (Warthin-Starry (WS) or Steiner) are preferred to detect Bartonella organisms; however, organisms are variably detectable, and these stains are technically challenging [3].

The histologic differential diagnosis of CSD lymphadenitis primarily includes Kikuchi necrotizing lymphadenitis (KNL), Kawasaki disease and other infectious processes, such as tularemia, mycobacterial infection, brucellosis, fungal infection, lymphogranuloma venereum (LGV) and lymphadenitis associated with idiopathic granulomatous mastitis (especially when in a young female patient, though in this case, the patient was male) $[1,3,20]$. LGV mainly involves the inguinal lymph node. Serologic studies, special stains for Bartonella, and molecular studies might be required to distinguish between the two.

In our case, histopathologically, the lesion showed suppurative granulomatous inflammation, and the WS stain detected clumps of bacilli, highly suggestive of CSD but not definitive [21,22]. Chondrogiannis et al. described a sero-negative CSD case confirmed by PCR and mentioned limitations of histopathology [21]. However, they also mentioned histopathologic examination of lymph nodes is crucial for exclusion [21,23]. 
In our case, the serology for tularemia was negative. No microorganism was found by a Brown-Brenn Gram stain. No fungal species were detected by the PAS stain.

KNL can be histologically similar to CSD, however, KNL lacks neutrophils or epithelioid cells with granulomatous arrangements [24].

Ultimately, no single criterion can be considered the diagnostic gold standard [9]. In 2000, Margileth proposed a diagnostic criteria for $B$. infection (three of 4 of the following): 1 . cat or flea contact regardless of presence of inoculation site, 2. negative serology for other causes of adenopathy, sterile pus aspirated from a node, a positive PCR assay, and/or liver/spleen lesions seen on CT scan, 3. positive enzyme immunoassay or IFA assay with a titer ratio of $\geq 1: 64$, and 4 . biopsy showing granulomatous inflammation consistent with CSD or a positive WS stain $[9,25]$.

We report a case of CSD, sero-negative but confirmed by PCR, with histopathologic features. Characteristic histopathologic findings combined with the WS stain, may contribute to the diagnosis.

\section{Consent}

Written informed consent was obtained from the patient for publication of this Case Report and accompanying images. A copy of the written consent is available for review by the Editor-in-Chief of this journal.

\section{Abbreviations}

CSD: Cat scratch disease; KNL: Kikuchi necrotizing lymphadenitis; IFA: Indirect fluorescence assay; PCR: Polymerase chain reaction; LGV: Lymphogranuloma venereum.

\section{Competing interests}

The authors declare that they have no competing interests.

\section{Authors' contributions}

YRK, THB and TSL collected the clinical data. ORS made the final diagnosis of this disease. SYK performed serologic tests. THH performed PCR test. KJS and ORS drafted the manuscript. All authors have read and approved the final manuscript.

\section{Acknowledgement}

Here we express our thanks to professor Dong-Gun Lee (Division of Infectious Diseases, Department of Internal Medicine, College of Medicine, The Catholic University of Korea, Seoul, Korea) and professor Tae-Jung Kim (Department of Hospital Pathology, College of Medicine, The Catholic University of Korea) for their kindly and great help in correcting this manuscript.

\section{Author details}

'Department of Hospital Pathology, Uijeongbu St. Mary's Hospital College of Medicine, The Catholic University of Korea 271, Cheonbo-ro, Uijeongbu-si, Gyenggi-do 480-717, Republic of Korea. ${ }^{2}$ Department of Internal Medicine, The Catholic University of Korea, College of Medicine, Seoul, Korea. ${ }^{3}$ Department of Laboratory Medicine, Inje University Sanggye Paik Hospital, Seoul, Korea. ${ }^{4}$ Division of Zoonoses (CJD/Rabies/LB), Center for Immunology \& Pathology, National Institute of Health (Korea CDC), Seoul, Korea.

Received: 4 March 2014 Accepted: 12 March 2014

Published: 19 March 2014

\section{References}

1. Asano S: Granulomatous lymphadenitis. J Clin Exp Hematop 2012, $52: 1-16$.

2. Kaiser PO, Riess T, O'Rourke F, Linke D, Kempf VA: Bartonella spp.: throwing light on uncommon human infections. Int J Med Microbiol 2011, 301:7-15.

3. Lamps LW, Scott MA: Cat-scratch disease: historic, clinical, and pathologic perspectives. Am J Clin Pathol 2004, 121(Suppl):S71-S80.

4. Zeaiter Z, Fournier PE, Raoult D: Genomic variation of Bartonella henselae strains detected in lymph nodes of patients with cat scratch disease. J Clin Microbiol 2002, 40:1023-1030.

5. Carithers HA: Cat-scratch disease; notes on its history. Am J Dis Child 1970, 119:200-203.

6. Debre R, Lamy M, Jammet ML, Costil L, Mozziconacci P: Cat scratch disease. Sem Hop 1950, 26:1895-1904.

7. Klein JD: Cat scratch disease. Pediatr Rev 1994, 15:348-353. quiz 353.

8. Brenner DJ, O'Connor SP, Winkler HH, Steigerwalt AG: Proposals to unify the genera Bartonella and Rochalimaea, with descriptions of Bartonella quintana comb. nov., Bartonella vinsonii comb. nov., Bartonella henselae comb. nov., and Bartonella elizabethae comb. nov., and to remove the family Bartonellaceae from the order Rickettsiales. Int J Syst Bacteriol 1993, 43:777-786.

9. Florin TA, Zaoutis TE, Zaoutis LB: Beyond cat scratch disease: widening spectrum of Bartonella henselae infection. Pediatrics 2008, 121:e1413-e1425.

10. Brenner DJ, Hollis DG, Moss CW, English CK, Hall GS, Vincent J, Radosevic J, Birkness KA, Bibb WF, Quinn FD, Swaminathan B, Weaver RE, Reeves MW, O'connor SP, Hayes PS, Tenover FC, Steigerwalt AG, Perkins BA, Daneshvar MI, Hill BC, Washington JA, Woods TC, Hunter SB, Hadfield TL, Ajello GW, Kaufmann AF, Wear DJ, Wenger JD: Proposal of Afipia gen. nov., with Afipia felis sp. nov. (formerly the cat scratch disease bacillus), Afipia clevelandensis sp. nov. (formerly the Cleveland Clinic Foundation strain), Afipia broomeae sp. nov., and three unnamed genospecies. J Clin Microbiol 1991, 29:2450-2460.

11. Dolan MJ, Wong MT, Regnery RL, Jorgensen JH, Garcia M, Peters J, Drehner D: Syndrome of Rochalimaea henselae adenitis suggesting cat scratch disease. Ann Intern Med 1993, 118:331-336.

12. Perkins BA, Swaminathan B, Jackson LA, Brenner DJ, Wenger JD, Regnery RL, Wear DJ: Case 22-1992-pathogenesis of cat scratch disease. N Engl J Med 1992, 327:1599-1601.

13. Regnery RL, Olson JG, Perkins BA, Bibb W: Serological response to "Rochalimaea henselae" antigen in suspected cat-scratch disease. Lancet 1992, 339:1443-1445.

14. Smith DL: Cat-scratch disease and related clinical syndromes. Am Fam Physician 1997, 55:1783-1789-1793-1784.

15. Rocco VK, Roman RJ, Eigenbrodt EH: Cat scratch disease. Report of a case with hepatic lesions and a brief review of the literature. Gastroenterology 1985, 89:1400-1406.

16. Agan BK, Dolan MJ: Laboratory diagnosis of Bartonella infections. Clin Lab Med 2002, 22:937-962.

17. Hansmann $Y$, DeMartino S, Piemont $Y$, Meyer N, Mariet $P$, Heller R, Christmann D, Jaulhac B: Diagnosis of cat scratch disease with detection of Bartonella henselae by PCR: a study of patients with lymph node enlargement. J Clin Microbiol 2005, 43:3800-3806.

18. Sander A, Posselt M, Bohm N, Ruess M, Altwegg M: Detection of Bartonella henselae DNA by two different PCR assays and determination of the genotypes of strains involved in histologically defined cat scratch disease. J Clin Microbiol 1999, 37:993-997.

19. Anderson BE, Neuman MA: Bartonella spp. as emerging human pathogens. Clin Microbiol Rev 1997, 10:203-219.

20. Lin CH, Hsu CW, Tsao TY, Chou J: Idiopathic granulomatous mastitis associated with risperidone-induced hyperprolactinemia. Diagn Pathol 2012, 7:2.

21. Chondrogiannis K, Vezakis A, Derpapas M, Melemeni A, Fragulidis G: Seronegative cat-scratch disease diagnosed by PCR detection of Bartonella henselae DNA in lymph node samples. Braz J Infect Dis 2012, 16:96-99.

22. Wear DJ, Margileth AM, Hadfield TL, Fischer GW, Schlagel CJ, King FM: Cat scratch disease: a bacterial infection. Science 1983, 221:1403-1405 
23. Rolain JM, Lepidi H, Zanaret M, Triglia JM, Michel G, Thomas PA, Texereau M, Stein A, Romaru A, Eb F, Raoult D: Lymph node biopsy specimens and diagnosis of cat-scratch disease. Emerg Infect Dis 2006, 12:1338-1344.

24. Ioachim HL, Medeiros L: Cat-Scratch Lymphadenitis. In loachim's Lymph node pathology. 4th edition. Philadelphia: Lippincott Williams \& Wilkins; 2009:110-114.

25. Margileth AM: Recent advances in diagnosis and treatment of cat scratch disease. Curr Infect Dis Rep 2000, 2:141-146.

doi:10.1186/1746-1596-9-62

Cite this article as: Shin et al:: A case report of seronegative cat scratch disease, emphasizing the histopathologic point of view. Diagnostic Pathology 2014 9:62.

\section{Submit your next manuscript to BioMed Central and take full advantage of:}

- Convenient online submission

- Thorough peer review

- No space constraints or color figure charges

- Immediate publication on acceptance

- Inclusion in PubMed, CAS, Scopus and Google Scholar

- Research which is freely available for redistribution 